\title{
Rumi whirling in a secular age: Applying medieval Sufi wisdom to the questions of our day
}

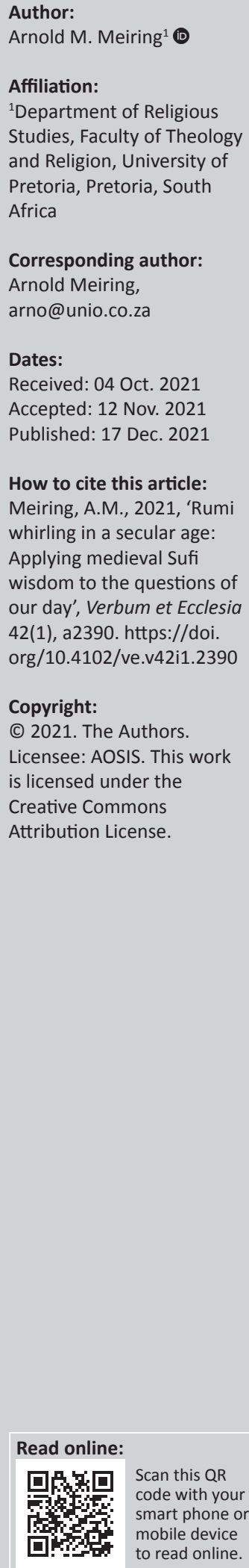

In a secular society, obsessed with materialism and consumerism, the 13th-century mystical teacher and poet, Jalaluddin Rumi (1207-1273), has found a surprisingly widespread following. While his work is often misunderstood and diluted, this research proposed the opposite: that Rumi may broaden his modern admirers' worldview and bring about an encounter with God. This study thus applied the insights of an 800-year-old mystic to the questions of today. The research comprised of a qualitative literature research method that first explored the life and writings of Rumi, and then investigated the issues and yearnings of a secular society as proposed by philosopher Charles Taylor. The study showed that Rumi may indeed open up the enclosed secular worldview by adding significance to our living, God to our loving and hope to our dying.

Intradisciplinary and/or interdisciplinary implications: This article was a study in religion applying the work of a medieval Sufi mystic to the philosophical questions of today. It also considered Anatolian history and Persian literature and offered philosophical options. It further related to missiology, as well as systematic and practical theology.

Keywords: Rumi; Sufism; New Sufism; Islam; Persian poetry; Charles Taylor; secularism; time; living; death.

\section{The Rumi phenomenon}

The mystical poet, Jalaluddin Rumi (1207-1273), has gained tremendous popularity in the last two decades. Although his work was always highly regarded in the Islamic world, he was recently celebrated in the wider international community to the extent that the United Nations Educational, Scientific and Cultural Organisation (UNESCO) even declared 2007 - the 800th anniversary of Rumi's birthday - as Rumi year. In the Middle East, Rumi's legacy is claimed by numerous countries, among them Turkey, Iran, and even Afghanistan, while in the Western world, especially the United States of America, the Rumi phenomenon, as El-Zein (2000:71-72) calls it, is in full swing. Popular publications ${ }^{1}$ and movies (Shiva 2018) on his life have been received enthusiastically (Kahteran 2009:51; Lewis 2007:7; Zare-Behtash 2017:97).

Part of Rumi's appeal lies in his beautiful poems. Often compared to Khalil Gibran, his poems have been recorded by Madonna, ${ }^{2}$ Rosa Parks, ${ }^{3}$ Goldie Hawn ${ }^{4}$ and Deepak Chopra, ${ }^{5}$ while the British rock band, Coldplay, ${ }^{6}$ even recorded a song about him and his words. Even more astounding, Beyoncé Knowles and her husband, Shawn Carter (Jay Z), named their daughter Rumi, and fashion house Donna Karan featured his poems during a fashion show (El-Zein 2000:72-73; Shiva 2018).

Rumi's poems deal with all aspects of human life, including spirituality, love and religion. According to Shahram Shiva, he proposed a love-based religion, instead of a fear-based one, to offer his followers a 'life journey free of guilt, fear and shame'. In addition to his psychological insights, he also addressed a range of political issues, such as dealing with 1.Most notably The Forty Rules of Love (2010) by acclaimed Turkish author, Elif Shafak.

2.[Merlin] Tommy Boy Music LLC (on behalf of Rasa Music) (2015) Madonna reading a poem by Rumi.

3.Tommy Boy Music LLC (2021). Looking For Love - Rosa Parks.

4.Tommy Boy Music (2021). The Meaning of Love - Goldie Hawn.

5. Hermes Music Porque Amamos La Musica (2018) Rumi Poems (The Madness of Love) by Deepak Chopra.

6.Parlophone Records Limited (2018). Kaleidoscope. 
minorities. His philosophy was praised by Hegel, 7 quoted by Ghandi and repeated by Walt Whitman ${ }^{8}$ (Basak 2017:113; Kahteran 2009:55; Lewis 2007:12; Shiva 2018:2-5; Zare-Behtash 2017:97).

Rumi is possibly best known for his thoughts on pluralism. ${ }^{9}$ $\mathrm{He}$ is a peacemaker and bridge builder between East and West - Franklin Lewis calls it his 'irenic effect' (2007:17). His scope includes all religions and cultures, finds common grounds between these, and he calls on his followers to ignore the differences and instructs them on interreligious dialogue (Kahteran 2009:51, 59; Shiva 2018:2-5; Zare-Behtash 2017:97).

In his own words:

I am neither of the West, nor of the East. Not of the ocean, nor an earthly beast...

My place is the no-place. My image is without face. Neither of body nor the soul. I am of the Divine Whole. (D 116; Akbari 2021:62). ${ }^{10}$

Basak (2017) concludes that:

$[H]$ e has been so many things to so many people ... (Rumi) was not only a philosopher, a poet, mystic and the founder of a Sufi ${ }^{11}$ order, he was a man of profound insight into the nature of human existence and possibly the greatest mystical poet of any age. (p. 113)

\section{The life of Rumi}

Who was this Rumi? Jalaluddin ${ }^{12}$ Muhammad was born on 30 September $1207^{13}$ in Balkh, on the eastern edge of the Persian Empire (today's Afghanistan). It was a challenging but constructive time for Islam. The Islamic world was under threat from the Mongol invaders ${ }^{14}$ in the East that burst

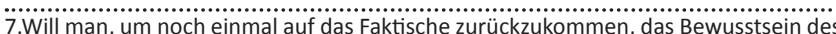
Einen nich nach der indischen Spaltung einesteils in die bestimmungslose Einheit des abstrakten Denkens, andernteils in die ermüdende, selbst litaniatig werdende des abstrakten Denkens, andernteils in die ermüdende, selbst litaneiartig werdende Durchführung am Besonderen, sondern es in der schönsten Reinheit und Erhabenheit sehen, so muss man sich bei den Mohammendanerrn umsehen. Wenn z. B. bei dem vortrefflichen Dschelaleddin Rumi insbesondere die Einheit der Seel mit dem Einen, auch diese Einheit als Liebe hervorgehoben wird, so ist diese geistige Einheit eine Erhebung über das Endliche und Gemeine, eine Verklärung des Natürlichen und Geistigen, in welcher eben das Äusserliche, Vergängliche des unmittelbaren Natürlichen wie des empirischen, weltlichen Geistigen ausgeschieden und absorbiert wird' (Hegel 1930:386-387).

8.Walt Whitman (1819-1892) is one of the most influential American poets of the 19th century. Moghaddas and Boostani (2015) researched and recorded Rumi's influence on Whitmann. Below I quote Whitman's poem 'A Persian Lesson' that echoes Rumi's poetry.

9.Philosophic pluralism refers to the idea that the multiplicity and diversity of things rather than their unity is the more striking and important fact (Britannica 2008).

10.Interestingly, one of the most quoted ecumenical lines is now suspected of not belonging to him (Lewis 2007:5-6):

O Muslims, what is to be done! I do not recognise myself

I am neither Christian, nor Jewish, I am not Parsi or Muslim

11.Sufism is a mystical belief and practice in which Muslims seek to find the truth of divine love through direct personal experience of God. It first appeared in the 7th century as an ascetic reaction against the perceived worldliness of the Umayyad period (661-749). Later mystics, like Ibn Sina, developed it further by synthesisin the Falsafa (philosophical, especially neoplatonist) and Kalam (rationalist) traditions. Al-Ghazzali (d 1111) concluded the classical period. Rumi founded one of the subsequent orders (Schimmel 2019).

12.The Arabic is variously transcribed as Jalal al-Din, Jalâluddîn, Jelaluddin, Jalal-uddin, Jalâl al-Din; I follow the majority of authors by using 'Jalaluddin'.

13. New historic criticism also offers other possibilities relating to the lunar calendar (Lewis 2007:8). For the sake of this study, I keep to the traditional dates.

14.Interestingly, the Mongols converted to Islam in 1316 (Iqbal 1956:4-11). across the empire and shocked the inhabitants of Western Asia and Europe. At the same time, the Crusades had devastated the Middle East, making inroads into Islamic territory - especially in Spain where Muslim rule was shrinking (Armstrong 2000:83; Iqbal 1956:4-11).

There was also internal upheaval. According to Iqbal (1956:3), 13th-century Islam no longer represented the best it had to offer to the world. It was decaying and losing its vigour and authority. Simultaneously, Karen Armstrong (2000:69-71) contends that it was also a creative time. As the central religious authority faltered, breakaway caliphates produced a new order and developed various cultural centres that were vibrant and tenacious. It was a time of new possibilities and new spiritualities; one of these was the propagation of mysticism. Christianity produced Hildegard von Bingen, Catherine of Siena, Mechthild of Magdeburg and Meister Eckhart; Hinduism yielded the Bhakti movement; and AlGhazzali formulated an Islam mysticism. ${ }^{15}$ It was the time of Francis of Assisi, Dante Alighieri and Rumi (Armstrong 2000:84-85; Iqbal 1956:8-9; Lewis 2007:10).

Rumi descended from a long line of Islamic jurists, theologians and mystics. His father, Bahauddin Vled, ${ }^{16}$ was a famous scholar who taught religion, mysticism (in the tradition of Al-Ghazzali) and philosophy. He was highly esteemed, attaining the title of Sultan-ul-'Ulama, 'king of scholars'. His mother, in turn, was related to the king of Khorasan in the Eastern Persian Empire. Their family was powerful, wealthy and politically connected (Armstrong 2000:76; Shiva 2018:6-11).

When Rumi was 12 years old, Balkh was invaded by the Mongols. In order to escape from the massacres, his father fled with his family - first to Damascus, then to Nishapur and finally settled in the town of Konya in south-central Turkey, which was then the capital of the Seljuk Empire. According to legend, Bahauddin loaded 90 camels with just his books when the family fled the Mongal army, showing their learned linage. It was here that Jalaluddin acquired the name Al-Rumi ${ }^{17}$ (Armstrong 2000:86-87; Barks 2010:1-6; Basak 2017: 114; El-Zein 2000:71; Iqbal 1956:1, 48-61; Lewis 2007:19-22).

In Konya, the family continued to thrive. Bahauddin became the head of the madrassa and authored the Ma'arif, a book on divine sciences. When his father died in 1230, Rumi assumed his father's position as shaykh in the learning community of Konya and continued to teach and preach there. Rumi gained a wide reputation as a devout scholar and his school reportedly numbered over 10000 students. He also climbed

15.Al-Ghazzali popularised Sufism already in 1058-1111, building on the likes of Ibn Sina (980-1037) who merged the Kalam and Falsafa traditions that later brought about this mystical trajectory in Islam. Other mystics like Ibn-Rushd (1126-1198) then built on Ibn Sina and Al-Ghazzali. Rumi took Sufism into the 13th century (Armstrong 2000:71).

16.Also spelled Baha'uddine Valad, Bahaeddin Veled and Bahauddin.

17.Al-Rumi means 'the Roman' or 'belonging to Rome'. It refers to an area of Anatolia which belonged to the Eastern Roman (Byzantine) Empire but was ruled by the Muslim Turks. 
the social ladder and cultivated, according to Shiva (2018: 6-12), favourable friendships ${ }^{18}$ (Armstrong 2000:86-87; Barks 2010:1-6; Basak 2017:114; El-Zein 2000:71; Iqbal 1956:1, 48-61; Lewis 2007:19-22).

Then, in the autumn of 1244, Rumi met Shamsi-Tabrizi (known as the Shams) and it changed his life. Shams was a fierce and uncompromising figure, 'God-man or man-God' according to Barks (2010:2), who wandered the Middle East. He spent days in mystical meditation, and also worked as a labourer to support himself. Shams never stayed long in one place, and whenever students began to gather around him, as they inevitably did, he disappeared: he was nicknamed Parinda or 'the Bird' as he would not stay in one place for too long. Some even believed he could fly or transport his essence at will as he was seen to be in two different and distant cities at the same time! Sensing that he was approaching his own death, Shams asked God to reveal his favourite to him, so that Shams could teach the mysteries of divine love to this person. An inner voice then sent him to Jalaluddin (Barks 2010:2; Shiva 2018:6-11).

Rumi and Shams' first meeting left Rumi dazed. There are numerous versions of their first conversation; Coleman Barks (2010) tells it as follows:

One day, as Shams sat at the gate, Rumi came by riding on a donkey, surrounded by students. Shams rose and took the bridle. 'Money changer of the current coins of esoteric significance, knower of the names of the Lord, tell me. Who is greater, Muhammad or Bestami ${ }^{19}$ ?' 'Muhammed is incomparable among the saints and prophets'. 'Then how is it he said', 'We have not known You as You should be known', while Bestami cried out, 'How great is my glory!'. Rumi fainted when he heard the depth of the question and fell to the ground. When he revived, he answered, 'For Muhammad the mystery is always unfolding, while Bestami takes one gulp and is satisfied'. (p. 2; Iqbal 1956:108-111)

Immediately afterwards, the two spent weeks in a mystical conversation, during which time Shams initiated Rumi into his mystical teachings. Before this encounter, Rumi did not write poetry, but meeting Shams '(made) poetry flow from him'. This became a special friendship, wherein Shams played the role as a spiritual guide to Rumi (El-Zein 2000:91; Lewis 2007:23-24).

They were together for about three and a half years. Initially, Rumi and Shams were together for six months, but then some of Rumi's jealous disciples drove Shams away (twice), only to be persuaded to return by Rumi's son, Sultan Veled. When Shams disappeared the last time, it was rumoured that he was killed by these disciples of Rumi, in cahoots with Rumi's other son, Ala Al-Din. Even though

18.According to Shiva (2018), Rumi indulged in personal contacts, and he was known to pull and offer favours. Shiva recounts that Rumi had a close friendship with to pull and offer favours. Shiva recounts that Rumi had a close friendship with Zarkoob, a goldsmith in Konya; as it was socially unacceptable for a member of the elite class to socialise with a merchant, Rumi arranged that his eldest son, Sultan
Walad, marry Zarboob's daughter to formalise their connection.

19.Bestami (d. 874) was a mystic known for the boldness of his expressions of union with God.
Shams vanished, he remained very much alive to Rumi as an eternal guide (El-Zein 2000:91; Lewis 2007:23-24; Shiva 2018:6-11).

Rumi composed two major works of poetry: The first is called the Diwan Shamsi Tabrizi ${ }^{20}$ which comprises a collection of poems under the name of the Shams. Rumi called this after Shams as it came to him in a 'spontaneous overflow' of emotion due to his friendship and loss of Shams; it was thus inspired by Shams. The Diwan Shamsi Tabrizi contains about 40000 lyrical poems and quatrains and deals mostly with the philosophical and mystical thoughts that they shared in their conversations.

Rumi's second work is the more sober Mathnawi. ${ }^{21}$ The Mathnawi's subtitle explains it as: 'the principles of the principles of the principles of religion concerning the unveiling of the mysteries of union and certitude'. It is a long didactic poem of about 26000 rhymed couplets that offers a more popular work, recalling anecdotes, moral stories, life lessons, folk humour and satirical tales that Rumi taught his students. The Mathnawi is known as the Sufi scripture; it celebrates the Sufi lifestyle '... which can make everyone an indomitable hero of a battle waged perpetually in the cosmos and within the soul' (Armstrong 2000:87). The Mathnawi is also sometimes hailed as the Quran in the Persian tongue ${ }^{22}$ (El-Zein 2000:71-72; Farivar 2001; Lewis 2007:11; Shiva 2018:2-5; Zare-Behtash 2017:98).

Upon his death in 1273, Rumi's son, Sultan Veled, systemised his ideas and developed a framework of his beliefs and the subsequent rituals and ceremonies. Rumi's grandson, Ulu Arif Celebi, further contributed to his legacy by introducing prayers and a sisila-lineage. His followers came to be known as the Mawlawi ${ }^{23}$ brotherhood that spread Rumi's mysticism in the Ottoman Empire and the rest of the world as they preached spiritual renewal and upliftment today they are strewn across the globe (Basak 2017:114; ElZein 2000:72).

The best-known legacy of Rumi is the whirling sema dance in which dervishes - members of Rumi's Sufi order would turn around with open arms, their right hands facing the sky and their left hands facing the earth, while simultaneously repeating the names of God with each step. While this dance is meant as a prayer, it has become a bit of a tourist attraction in Turkey (to the utter dismay of Rumi's true supporters). I will return to this below (Basak 2017:116-118).

20.Also known as the Divan-e Shams or Al-Diwan al-Kabir. While this collection was first compiled in Persian, RA Nicholson published the best-known early European edition in 1898 (Chittick 1983:5-6; Lewis 2009:1-12). This article used later the translations by Chittick (1983), Schimmel (1993) and Barks (2010) (listed in the references).

21.Or Masnawi-i Ma'anawi. According to legend, Rumi dictated this collection to his disciple, Husam al-Din Chalabi, between 1258 and 1273. This was also translated by Nicholson in eight volumes between 1925 and 1940 (Chittick 1983:5-6; Lewis 2009:1-12).

22.Rumi developed the Mathnawi as a mystical commentary of the Quran, quoting the Quran throughout and supplying Persian commentary (Lewis 2007:11).

23.Or Mevlevi. 


\section{New Sufism}

Rumi's immense popularity has had the unfortunate consequence that Rumi's work has become separated from its Islamic roots and theology, and been appropriated by many other philosophies and religions to reinforce its own ideas. Rasim Basak explains that just like commercialisation and secularisation have stripped Christmas and Easter of its religious origins and reduced it to seasonal cults with secular iconographies and modes of celebration (in contrast to the religious icons and rituals), the same forces are threatening to also transform and reduce the theology and depth of Rumi's work (2017:117-118).

Rumi's concepts of love have, according to Basak, been 'vulgarised', mutilated from its original understanding of existence to become a marketing strategy and tool, 'sold as sex', with Rumi being made into a 'love guru'. The sema dance, intended as a prayer, has become a secularised form of self-expression. Rumi's philosophy has been misused to endorse even Buddhism and Taoism, and his teachings exploited for political control by the secular Ataturk administration $(2017: 117,118,121)$.

In addition, Amira El-Zein (2000:73) ventures that Rumi's work is used to produce what she calls 'New Sufism'. She describes New Sufism as a complex phenomenon that mixes New Age and Sufi terminology to offer practical advice, gleaned from works such as Rumi's, but reduced to a shallow and superficial spirituality. El-Zein (2000:74-76) bemoans that 'the basic Islamic component in Rumi's work has been diluted in the soup of the "New Sufism" to the extent that Islam appears in it as mainly folkloric'.

\section{Turning tables on secularism}

The misappropriation of Rumi's work is ironic as, according to Basak (2017:114), Rumi and his fellow Islamic philosophers (e.g. Ghazzali and Ibn-ul Arabi) set out to defend spirituality and idealism against materialism, scepticism ${ }^{24}$ and dogmaticism. ${ }^{25}$ Still, Kazzazi and Vafayi (2016:1) argue that Rumi did not hold a negative view of the secular world, but rather used everyday stories and mundane activities to lead his students to an encounter with the Ultimate and realise the goal of their creation.

So, while Basak and El-Zein convincingly show how Rumi's work is misused and cheapened by secular and consumerist culture, it seems that Rumi himself did not feel threatened by the secular forces of his day, but rather used the secular to bring his followers into a deeper spiritual awakening, as Kazzazi and Vafayi contend. Below I want to argue that Rumi can still do it. The fact that the exact same ideas of his, which are so often deprived of any theological (and Islamic) foundation, may also,

24.Scepticism (or skepticism) refers to the attitude of doubting knowledge claims, and challenging the rational grounds of accepted assumptions (Popkin 2020).

25.Quality of being dogmatic; inclined to lay down principles as undeniably true (Oxford University Press 2021). oppositely, turn a secular world towards a spiritual discovery and stirring.

Our modern world differs from Rumi's 13th century, and the challenges we face differ likewise; we are looking at Rumi from a modern view. Lewis (2007) warns that:

The glass from which we gaze at Rumi is somewhat obscured by the dross of time, because the world has changed, and when we read Rumi now, we project his meaning onto our changed world. (p. 7)

Nonetheless, perhaps Rumi can still teach our world something about $\mathrm{God}^{26}$ or bring about an encounter with the divine. Rumi's project was to help humans realise their inadequacy and illusory sense of selfhood by divesting themselves of egotism and selfishness, to then find that God is all that remains (Armstrong 2000:86). Since Rumi is so well-read and appreciated today, perhaps the whirling mystic can do it again, turning the tables on the secularism and New Sufism that dare to misuse him.

Philosopher Charles Taylor hints at such a possibility. He suggests that the immanentist $\mathrm{t}^{27}$ position of our secular age can be questioned. He argues that there is a 'spectre of meaninglessness' that has left humans feeling empty. This generates an unease and restlessness that will not go away (Smith 2014:129; Taylor 2007:717). He continues:

(There is) a number of ways in which our modern culture is restless at the barriers of the human sphere ... the search for meaning, the deepening of our sense of life through our contact with nature and art ... also death as an escape from the confines of life, to the paramount vantage point in which life shows its meaning. (Taylor 2007:726)

\section{Living}

One of the ways in which this unease is manifested is time: modernity did away with 'higher times', 'leaving us to the merely chronological tick-tock of secular time' (Smith 2014:129). However, Taylor (2007) maintains that human beings cannot live only in this unbearable concept of time; time should rather give us a sense of meaning:

Time for us continues to be marked by cycles, through which we orient ourselves. Even those who are most thoroughly immersed in the packed, measured schedules of a demanding career perhaps especially they - can be totally at a loss if their routine is interrupted. The frame gives a sense to their lives, distinguishing different moments from each other, giving each its sense, creating mini-kairoi to mark the passage of time. It's as though we humans have a need for gathered time, in one form or another. (p. 714)

It seems that a cyclical experience of time provides meaning and significance. Every cycle has its place and reason, cycles begin and end, and cycles heal. When looking at life through

26.I follow Armstrong's inclusive conception of 'God'.

27.Smith (2014:141) explains that Taylor's immanent frame refers to a 'constructed social space that frames our lives entirely within a natural (rather than a supernatural) order'. It follows that significance and meaning are sought 'within an supernatural) order'. It follows that significance and meaning are sought 'within an
enclosed, self-sufficient, naturalistic universe without any reference to enclosed, self-sufficient, nat
transcendence', an 'enclosure'. 
the cycles of time, transcendence enters our lives (Smith 2014:129-131).

It is said that when Rumi heard of Shams' murder, he was struck with the deepest grief. Then, 'upon hearing the hammering of the goldsmith, Rumi, in his grief, began to whirl in the marketplace'. And so the turning of the dervish was born ${ }^{28}$ (Basak 2017:115). The ensuing dance became the famous sema dance which the Mawlawi dervishes would replicate through the centuries, accompanied by a lamenting reed and a pacing drum.

The sema dance symbolises Rumi's view of a dancing universe - endlessly whirling. Through the music and the dance, Rumi's followers could share in the ecstatic experience of unity with this universe and recognise that everything is connected; nothing can be thought of as separable from others (Basak 2017:120): 'Stop acting so small ...' Rumi said '... you are the universe in ecstatic motion'.

Rumi not only wanted to reintegrate humans with the universe, but also reconnect them with God. Karen Armstrong explains that Rumi addressed his contemporaries' sense of cosmic homelessness and separation from God, and reminded them that God is the divine source of everything. Interestingly, Rumi believed that the greatest misfortune is when humans do not even feel 'the pain of severance from God' (Armstrong 2000:86).

Consequently, Rumi believed that the sema dancing revealed the presence and work of God to participants. Just as the dancing cloak whirls around the dancer, so the universe turns, dances, around God (El-Zein 2000:78):

The heavens are like a dancing dervish-cloak,

but the Sufi is hidden. Oh Moslems, who ever has seen a

cloak dance without a body within in?

The cloak dances because of the body, the body because of the spirit,

and love for the Beloved has tied the spirit's neck to the end of a string. (D20379-8029; Chittick 1983:328)

In addition, Rumi describes hearing the whirling universe proclaiming God. Annemarie Schimmel (1993) quotes W. Hastie's translation:

Sound drum and mellow flute, resounding Allah $\mathrm{Hu}^{30}$ dance, ruddy dawn, in gladness bounding, Allah Hu sun exalted in the centre, o thou streaming light; soul of all wheeling planets rounding Allah Hu. (p. 222)

When dancing Rumi's sema, followers not only discovered their connectedness to the universe and recognised God at the centre of it all, they also realised their true identity as

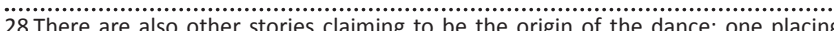
Rumi in a garden rather than a goldsmith's shop and marketplace (Basak 2017:116).

29.Refers to the Diwan Shansi Tabrizi verse (ghazal) no. 20379-20380.

30.'God is'. reflections of the Divine. In mystical fashion, the dance represented a union with God that leads to a reappropriation or rediscovery of the self (Basak 2017:116, 122): 'Love yourself, all the divine beauty and virtue is hidden in you' (Rumi in Basak 2017:122).

Although Rumi's dance is often commercialised and his poetry secularised, these may in fact undermine the closed, meaningless worldview of a secular society. While he did not use the same words as Taylor, his circular dance (and accompanying poems) established what Taylor envisaged: a dance that celebrates and interprets the movement of the universe - constricting and expanding, inhaling and exhaling, day and night, life and death - which also reveals God at its centre, connects humans to the 'chain of Being', and gives significance to human lives (El-Zein 2000:78).

\section{Loving}

Rumi is synonymous with love and that is also the main reason why the West is so enamoured with him. As described earlier, Rumi's teachings and verses on love are often stripped of its religious foundation; when they used Rumi's work in a show, Donna Karan's former president, Patti Cohen, claimed, 'I don't think of Rumi's poetry as religious. It is all about love' (cited in El-Zein 2000:76).

I believe that this view would not have put Rumi off in the least. Rumi felt that all love eventually led to God, and human love would in the end become something more. A celebration of love, found in Rumi's poems, may therefore be another opening into secular thinking, touching modern hearts with the transcendent (Kahteran 2009:59-60).

Rumi loved Shams, and changed after meeting him from 'an outwardly sober jurisprudent to $a[n]$ inwardly intoxicated celebrant of the mysteries of Divine love'. He even dedicated the 40000 couplets of the Divan-e Shams to Shams (ZareBehtash 2017:100). In a beautiful poem, Rumi sings of this friendship:

My hand always used to hold a Koran, but now it holds Love's flagon.

My mouth was filled with glorification, but now it recites only poetry and songs. (D 24875-76; Chittick 1983:3)

Passion for that Beloved took me away from erudition and reciting the Koran until I became as insane and obsessed as I am. I had followed the way of the prayer carpet and the mosque with all sincerity and effort. I wore the marks of asceticism to increase my good works.

Love came into the mosque and said, 'Oh great teacher! Rend the shackles of existence! Why are you tied to prayer carpets?'

(D 26404-06; Chittick 1983:3)

For Rumi, love was not in opposition to God, but rather it revealed God: love and Mosque complemented each other. As love was an attribute, a gift from God, all love became love for God. In addition, Rumi believed that love purged a person from impurities, pride, self-deceit and wickedness, thus also drawing humans to God who is good and pure. He 
discovered how his own love for Shams transformed into love for the Divine (El-Zein 2000:76; Kahteran 2009:59-60; Zare-Behtash 2017:101).

Poet that he was, Rumi continues to describe love as God's Buraq. The Buraq is a mythical animal in Islamic culture, described as 'a white animal, half mule, half donkey, with wings on its sides' that once transported the prophet Muhammad from Jerusalem to heaven and back to Mecca in one night (Ignatova 2020).

A call reached the lover from the world of his inmost mystery: 'Love is God's Buraq, put it to the gallop'! (D13550; Chittick 1983:214)

If love then becomes God's Buraq, love is God's vehicle that transports God to humans. Similarly, love as Buraq also carried humans to God. In one poem Rumi describes love as the path that the angel Gabriel showed the prophet Muhammad to ascend into heaven:

Mount upon Love and think not about the way!

For the horse of Love is very sure-footed.

Though the path be uneven, in a single bound

it will take you to the waystation (D 6922-33; Chittick 1983:214)

Without the Buraq of Love and the effort of Gabriel, how will you reach those stations like Muhammad? (D 30751)

As a path to heaven, love is the preferred way to reach heaven; much better than reason and intellect:

By the time the intellect has deliberated and reflected, love has flown to the seventh heaven. By the time intellect has found a camel for the Hajj love has circled the Kaaba (D 182; Chittick 1983:226)

In a closed, limited view of the world, Rumi made space for love as an objective, ontological independent reality that transports lovers to God (Kahteran 2009:59-60). Rumi turns his Sufi followers into wayfarers '... travelling back to the Beloved - that is, God ...'; his poems and teaching may well do it again to secular readers (Zare-Behtash 2017:101).

\section{Dying}

Charles Taylor (2007:720) interprets Nietzsche's famous line 'Alle Lust will Ewigkeit' to mean that '...love by its nature calls for eternity'. Death, especially the death of a loved one, demands something to remain, an ineradicable desire for eternity. If nothing remains of love beyond death, love loses its sense and meaning. Death makes us yearn for something more. Consequently, our love calls for a different view of death (Smith 2014:131; Taylor 2007:722-727).

So it is, Taylor argues, that death 'tips' us towards an 'open take' of reality, rather than a 'closed spin'. He continues (2007):

... (death) is the privileged site from which the meaning of life can be grasped. Death can offer a vantage point, beyond the confusion and dispersal of living.

A need for meaning, a desire for eternity, can press us against the boundaries of the human domain. But death in another way can offer a way to escape the confinement of this domain, to breathe the air beyond. (p. 723)
Rumi, too, had to deal with death. In 1273, the last year of his life, Konya was shaken by a number of earthquakes that brought fear and anxiety to the people of Konya. Rumi himself suffered from an illness that could not be cured and which would lead to his own death on 17 December. As a result, Rumi had to comfort his weeping and distraught followers and speak about death. Earlier, Rumi had to make his peace with the death of his soulmate, Shams. And so he developed his teaching on death.

Rumi believed that death did not exist: death was not the end of a life, but rather simply a change from one shape to another. He compared death to a seed that dies in one form, only to be born in another as a tree (Zare-Behtash 2017:103):

On the day of death, when my bier is on the move, do not suppose that I have any pain at leaving this world.

Do not weep for me, say not 'Alas, alas!' you will fall into the devil's snare - that would indeed be alas.

When you see my hearse, say not 'parting, parting!' That time there will be for me union and encounter.

When you commit me to the grave, say not 'farewell, farewell!' For, the grave is a veil over the union of paradise.

What seed ever went down into the earth which did not grow? Why do you doubt so regarding human seed? (D 1358; Schimmel 1993:325).

Rumi continued that death meant joining to God. He thus described death as a wedding with eternity, and dying means that the veil is removed between humans and God. Death was therefore a happy occasion, to be met with joy and delight, as a dying person has at last reached their true destination and permanent home (Zare-Behtash 2017:103).

Rumi further consoled his followers by arguing that as everything in the world is a sign of God, and because God's will determined all, God can also be seen and experienced in the death of a loved one. His impending death should give them hope and faith, rather than being the cause of doubt and heartache (Zare-Behtash 2017:103).

When Rumi died, the whole Konya - Muslims, Jews and Christians - attended his funeral prayers. His followers danced the sema for hours and hours, celebrating the evening as shab-i arus, the 'night of nuptial' (Zare-Behtash 2017:103):

When you come visiting my grave,

my roofed tomb will appear to you dancing;

do not come without tambourine to my tomb, brother!

For a grieved person does not fit in God's banquet!

(D 685/7102; Schimmel 1993:36)

Death was not something to be feared, but welcomed, sought. In order to taste some of the blessings that death would later bestow, Rumi taught his students to die while still alive by letting go of their ego, will and self, becoming silent and submitting to God (Basak 2017:120; El-Zein 2000:79-80):

Become silent and go by way of silence toward nonexistence, and when you become non-existent, you will be all praise and laud! (D 2628/27850; Schimmel 1993:243) 
The whirling sema dance also served as a symbol for dying and being united with God. Instead of resembling a selfexpression, as New Sufism claims, the idea was that dancers would forget themselves before God, letting go of the material for the spiritual. The dancers' costumes further underline this symbolic death: the white dress which dancers typically wear, called tennure, represents burial shroud, while the sikke headdress copies a tombstone-pillar and the hirka cloak worn over the dress is the grave of a dervish dancer. Likewise, the 1001-day training that dervishes undergo is called chilé, which literally means 'suffering'. All these enhance the idea that as humans move closer to death, they also come closer to God (Basak 2017:118):

\author{
Let go of your worries \\ and be completely clear-hearted \\ like the face of a mirror \\ that contains no images. \\ When it is empty of forms, \\ all forms are contained in it. \\ No face would be ashamed \\ to be so clear. \\ This is to love: to fly towards a secret sky, to cause a hundred \\ veils to fall each moment. \\ First, to let go of life. In the end, to take a step without feet. \\ To regard this world as invisible, and to disregard what appears \\ to the self. (Mirdal 2021:1212)
}

In contrast to human mortality, God remains as the true reality, as asserted in the confession 'There is no God, but God'.

Rumi affords death a meaning that (as Taylor contends) secular society craves. The death of a beloved can be tolerated when understood as Rumi suggests - it is simply another way of being - and furthermore a better existence in union with God. He discovers joy and celebration in death. In addition, Rumi suggests that death should be included in life and in a spirituality of letting go, submitting to the only Eternal. In the face of death, God may enter secular lives.

\section{Conclusion}

It seems that there is a good reason for Rumi's popularity today, and that he can offer even more than what is widely expected. His work nourishes the mystical hunger worldwide that resonates, according to Albert Nolan (2006:10), 'with our postmodern insecurities and uncertainties'. While Rumi is apparently not yet generally appreciated in South Africa, the mystical poet may indeed '... reawaken mystical spirituality in the West' (Basak 2017:113) and elsewhere, opening up the enclosed and self-sufficient secular worldview by adding significance to our modern way of living, God to our loving and hope to our dying.

A year before he died, American poet, Walt Whitman, echoed Rumi's voice in his poem 'A Persian Lesson'. This is indeed Rumi's lesson ...

FOR his o'erarching and last lesson the greybeard sufi,

In the fresh scent of the morning in the open air,

On the slope of a teeming Persian rose-garden,
Under an ancient chestnut-tree wide spreading its branches, Spoke to the young priests and students.

Finally my children, to envelop each word, each part of the rest, Allah is all, all, all - is immanent in every life and object,

May-be at many and many-a-more removes - yet Allah, Allah, Allah is there.

Has the estray wander'd far? Is the reason-why strangely hidden? Would you sound below the restless ocean of the entire world?

Would you know the dissatisfaction? the urge and spur of every life;

The something never still'd - never entirely gone? the invisible need of every seed?

It is the central urge in every atom,

(Often unconscious, often evil, downfallen,)

To return to its divine source and origin, however distant,

Latent the same in subject and in object, without one exception.

(Whitman 2018:713)

\section{Acknowledgements}

\section{Competing interests}

The author declares that he has no financial or personal relationships that may have inappropriately influenced him in writing this article.

\section{Author's contributions}

A.M.M. is the sole author of this research article.

\section{Ethical considerations}

This article followed all ethical standards for research without direct contact with human or animal subjects.

\section{Funding information}

This research received no specific grant from any funding agency in the public, commercial or not-for-profit sectors.

\section{Data availability}

Data sharing is not applicable to this article as no new data were created or analysed in this study.

\section{Disclaimer}

The views and opinions expressed in this article are those of the author and do not necessarily reflect the official policy or position of any affiliated agency of the author.

\section{References}

Akbari, T.T., 2021, 'Rumi's storytelling in the Masnavi toward the journey of contentment and mental wellbeing', MA thesis, University of Virginia, Charlottesville, VA.

Armstrong, K., 2000, Islam: A short history, Orion Books, London.

Barks, C., 2010, Rumi: The big red book: The great masterpiece celebrating mystical love and friendship, HarperCollins, New York, NY.

Basak, R., 2017, 'Secularization and the commercialization of Rumi', Journal of Current Researches on Social Studies 7(2), 113-124.

Britannica, 2008, 'Pluralism and monism', Encyclopaedia Britannica, viewed 08 November 2021, from https://www.britannica.com/topic/pluralismphilosophy. 
Chittick, W.C., 1983, The Sufi path of love: The spiritual teachings of Rumi, SUNY Series in Islamic Spirituality, SUNY Press, Albany, NY.

El-Zein, A., 2000, 'Spiritual consumption in the United States: The Rumi phenomenon', Islam and Christian-Muslim Relations 11(1), 71-85. https://doi. org/10.1080/095964100111526

Farivar, M., 2001, 'Rumi Madness', Wall Street Journal, viewed 20 August 2021, from https://www.wsj.com/articles/SB983494725204434037.

Hegel, G.W.F., 1930, Enzyklopädie der philosophischen Wissenschaften im Grundrisse Dritter Teil - Die Philosophie des Geistes Mit den mündlichen Zuzätzen, Herausgegeben, Frankfurt, Suhrkamp, 1970

Hermes Music Porque Amamos La Musica, 2018, Rumi Poems (The Madness of Love by Deepak Chopra, viewed 04 November 2021, from https://www.youtube.com/ watch?v=GT_nGaVzSXs.

Ignatova, P., 2020, 'The little flash of lightning' Buraq in Islamicart, Epoch, viewed 23 August 2021, from https://www.epoch-magazine.com/ignatovaflashoflightning.

Iqbal, A., 1956, The life and work of Jalal-ud-din Rumi, The Octagon Press, London.

Kahteran, N., 2009, 'Rumi's philosophy of love in the era of U-turned Islam', Kyoto Bulletin of Islamic Area Studies 2(2), 51-62.

Kazzazi, M. \& Vafayi, Z., 2016, 'Secularism in the stories of Rumi's Mathnavi', Didactic Literature Review (Persian Language and Literature Review) 8(31), 1-44.

Lewis, F., 2007, 'The icon and the man: In quest of the historical Rumi', Noruz Lecture, Foundation for Iranian Studies, George Washington University, Bethesda, MD March 2007.

Lewis, F.D., 2009, 'Foreword', in Jalāl al-Dīn Rūmī et al. (eds.), Mystical poems of Rumi, University of Chicago Press, Chicago, IL.

[Merlin] Tommy Boy Music LLC (on behalf of Rasa Music), 2015, Madonna reading a poem by Rumi, viewed 04 November 2021, from https://www.youtube.com/ watch?v=c3sMIZvDJ94.

Mirdal, G.M., 2012, 'Mevlana Jalal-ad-Din Rumi and Mindfulness', Journal of Religion and Health 51(4), 1202-1215. https://doi.org/10.1007/s10943-010-9430-z
Moghaddas, B. \& Boostani, M., 2015, 'The influence of Rumi's thought on Whitman's poetry', Theoretical and Applied Linguistics Series 1(10), 73-82. https://doi. org/10.18413/2313-8912-2015-1-3-73-82

Nolan, A., 2006, Jesus today: A spirituality of radical freedom, Double Story, Cape Town.

Oxford University Press, 2021, 'Dogmaticism', Lexico, viewed 08 November 2021, from https://www.lexico.com/definition/dogmaticism.

Parlophone Records Limited, 2018, Kaleidoscope, viewed 04 November 2021, from https://www.youtube.com/watch?v=h4ag7p5Tohw.

Popkin, R.H., 2020, 'Skepticism', Encyclopedia Britannica, viewed 08 November 2021 from https://www.britannica.com/topic/skepticism.

Schimmel, A., 1993, The triumphal sun: A study of the works of Jalaloddin Rumi, Persian Studies Series, SUNY Press, Albany, NY.

Schimmel, A., 2019, 'Sufism', Encyclopedia Britannica, viewed 08 November 2021 from https://www.britannica.com/topic/Sufism.

Shafak, E., 2010, The forty rules of love, Penquin Books, London.

Shiva, S., 2018, Rumi's untold story: From 30-year research, Rumi Network, viewed 14 May 2021, from http://rumi.net/about_rumi_main.htm.

Smith, J.K.A., 2014, How (not) to be secular: Reading Charles Taylor, Eerdmans, Grand Rapids, MI.

Taylor, C., 2007, A secular age, Belknap Press of Harvard University Press (Gifford lectures, 1999), Cambridge, MA.

Tommy Boy Music, 2021, The meaning of love - Goldie Hawn, viewed 04 November 2021, from https://www.youtube.com/watch?v=RN_KUVtHAk8.

Tommy Boy Music LLC, 2021, Looking for love - Rosa Parks, viewed 04 November 2021, from https://www.youtube.com/watch?v=KY1zQreoDoM.

Whitman, W., 2018, Leaves of grass, Lerner Publishing Group, Minneapolis, MN.

Zare-Behtash, E., 2017, "Images of "love" and "death" in the poetry of Jaláluddin Rumi and John Donne', International Journal of Applied Linguistics and English Literature 6(2), 97-105. https://doi.org/10.7575/10.7575/aiac.ijalel.v.6n.2p.97 